\title{
COMPARISON BETWEEN DYNAMIC HEADSPACE AND HEADSPACE SOLID-PHASE MICROEXTRACTION FOR GAS CHROMATOGRAPHY OF BTEX IN URINE
}

\author{
Irena BRČIĆ KARAČONJI and Ljiljana SKENDER \\ Institute for Medical Research and Occupational Health, Zagreb, Croatia
}

Received in June 2007

Accepted in October 2007

\begin{abstract}
The aim of this study was to compare two extraction procedures: dynamic headspace-purge and trap (PT) and headspace solid-phase microextraction (HS-SPME) for gas chromatographic determination of benzene, toluene, ethylbenzene, and isomeric xylenes (BTEX) in urine with photoionization (PID) and mass spectrometric (MS) detection, respectively. Both methods showed linearity in the range of interest [(50-2000) ng L L-1], good accuracy ( $80 \%$ to $100 \%$ ), and repeatability (RSD $\leq 11 \%)$. Detection limits were in the low ng $\mathrm{L}^{-1}$ level for both methods, although slightly greater sensitivity was found for the PT method. In comparison with PT, HS-SPME was simpler and required less time for analysis.

Although the analytical features of both examined methods are appropriate for biomonitoring of environmental exposure to BTEX, only the HS-SPME-GC-MS method is recommended for routine analysis of BTEX in urine. The method was applied for the quantitative analysis of BTEX in urine samples collected from non-smokers $(n=10)$ and smokers $(n=10)$.
\end{abstract}

KEY WORDS: accuracy, GC-MS, PID, purge and trap, repeatability, SPME

Benzene, toluene, ethylbenzene, $m-, p-$, and oxylene (BTEX) are ubiquitous pollutants of the indoor and outdoor human environment. Two main sources of these compounds are traffic and tobacco smoking (1). BTEX are widely used in the manufacture of paints, synthetic rubber, agricultural chemicals and chemical intermediates (2). BTEX are hazardous carcinogenic and neurotoxic compounds, and are classified as priority pollutants by the US Environmental Protection Agency (EPA), in particular benzene, which the International Agency for Research on Cancer (IARC) classified as a carcinogen in humans (3).

In non-occupational exposure BTEX were usually analysed in blood (4-7) or exhaled breath (8). With development of more sensitive analytical techniques, analysis of those compounds in the urine has become the method of choice due to simplicity and noninvasive sample collection. Since it is not known for
BTEX to occur in human urine as a result of normal physiological metabolism, the finding of measurable concentrations of BTEX in the urine should reflect exposure to these aromatic compounds. At the level of environmental exposure, the concentration of BTEX excreted unmodified in the urine is low; the proportion is usually in the order of $1 \%$ or less of the absorbed dose (9), so the quantification of BTEX in the urine of general population has become possible thanks to the development of the very sensitive analytical techniques which permit determination at levels as low as $\mathrm{ng} \mathrm{L}^{-1}(1,5,10)$. Several instrumental variations are described for the low level BTEX determinations in the urine. These include different sampling techniques such as dynamic headspace (thermal desorption, TD and purge and trap, PT) (10-12) and headspace solid-phase microextraction (HS-SPME) $(1,5,13)$ followed by gas chromatographic separation and 
flame ionization (10-12) and/or mass spectrometric $(1,5,10,13)$ detection.

Headspace sampling (HS) is suitable for BTEX determination in the urine because of their volatility. This technique can be performed in a static or a dynamic way. Static headspace involves sampling gas phase aliquot over the sample using a gas tight syringe after equilibration in a sealed vial. Dynamic headspace enriches volatiles caught by a cold trap or an inert support (e.g. Tenax), by stripping them continuously with an inert gas flow through the sample. Headspace solid-phase microextraction, developed by Zhang and Pawliszyn (14) to evaluate volatile compounds from water, is an advancement in the static headspace approach. With this sampling technique, volatile substances from the headspace of sample are adsorbed and concentrated onto a fusedsilica fibre coated with a thin layer of a selective coating [usually $100 \mu \mathrm{m}$ of polydimethylsiloxane (PDMS) for BTEX].

The aim of this study was to compare BTEX extraction using PT and HS-SPME, and to find out which of the two procedures could be recommended for routine BTEX analysis in the urine. HS-SPME was applied for the quantitative analysis of BTEX in the urine samples collected from 20 healthy adults without any known occupational BTEX exposure.

\section{MATERIALS, METHODS, AND SUBJECTS}

\section{Materials}

Benzene, toluene, ethylbenzene, o-, m-, p-xylene, and methanol were analytical-grade-purity products of Merck (Darmstadt, Germany). Standard reference material for BTEX with $2000 \mu \mathrm{g}$ of each compound per $\mathrm{mL}$ of methanol was purchased from Supelco (Bellefonte, USA) and an aqueous emulsion (30\%) of Antifoam A concentrate from Sigma Chemical (St. Louis, USA). Headspace vials (6 mL) with PTFE septum and holed aluminium caps, hand crimper, and decapper were obtained from Varian (Harbor City, USA).

\section{Standard Preparation}

Stock solutions were prepared by two serial dilution steps in methanol. Stock solution A was prepared by spiking $3 \mu \mathrm{L}$ of each analyte to $10 \mathrm{~mL}$ of methanol. Stock solution B was prepared by dilution of $150 \mu \mathrm{L}$ of stock $A$ to $10 \mathrm{~mL}$ of methanol for the PT method, and $50 \mu \mathrm{L}$ of stock A to $10 \mathrm{~mL}$ of methanol for HSSPME. Working standards were prepared by spiking known amounts of stock B into deionized water, purified under a stream of dry nitrogen at $50{ }^{\circ} \mathrm{C}$ for 4 hours. One hundred $\mu \mathrm{L}$ of working standards were added to $9.9 \mathrm{~mL}$ of blank urine for the PT method and to $0.9 \mathrm{~mL}$ of blank urine for the HS-SPME method. The stock solutions were kept at $-20^{\circ} \mathrm{C}$, and working standards were freshly prepared every day.

The urine used for standard preparation was collected from non-smoking, occupationally nonexposed donors. Pooled urine was analysed before spiking, and the calibration curves were corrected for its BTEX content.

The samples prepared using the PT procedure were analysed by gas chromatography (GC) with photoionization detection (PID) and those prepared using the HS-SPME procedure by gas chromatographymass spectrometry (GC-MS).

\section{PT-GC-PID procedure}

The purge vessel containing $10 \mathrm{~mL}$ of urine and (0.5-1.0) mg of lyophilisated antifoam A was flushed with helium for 10 minutes at room temperature $\left(21^{\circ} \mathrm{C}\right)$ to purge volatile components. These components were transferred by carrier gas (helium) to a fused silica trap, and cooled to $-100{ }^{\circ} \mathrm{C}$ by liquid nitrogen. After the refocusing of components, the cold trap was flash-heated $\left(20{ }^{\circ} \mathrm{C}\right.$ for $\left.1 \mathrm{~min}\right)$, and the components were injected onto the Rtx-624 (Restek, Bellefonte, USA) capillary column ( $60 \mathrm{~m} \times 0.32 \mathrm{~mm}$ I.D., $1.8 \mu \mathrm{m}$ film thickness) where they were separated. We used a Varian 3800 gas chromatograph, equipped with a CP-4010 Purge and Trap Injector (PTI), Thermal Desorption Cold Trap Injector (TCT) (Chrompack, Middleburg, Netherlands), and photoionization detector (Varian, Walnut Creek, CA, USA). After injection, the column temperature was programmed to maintain at $70^{\circ} \mathrm{C}$ for the first $10 \mathrm{~min}$, then rise to $150{ }^{\circ} \mathrm{C}$ at the rate of $6{ }^{\circ} \mathrm{C} \mathrm{min}^{-1}$ and maintain this temperature for $4 \mathrm{~min}$, then again rise to $200^{\circ} \mathrm{C}$ at the rate of $30{ }^{\circ} \mathrm{C} \mathrm{min}^{-1}$ and maintain this temperature for another $3 \mathrm{~min}$. The flow rate of the carrier gas (helium) was $1 \mathrm{~mL} \mathrm{~min}{ }^{-1}$. The make-up gas (nitrogen) flow was $29 \mathrm{~mL} \mathrm{~min}^{-1}$. The detector temperature was $230^{\circ} \mathrm{C}$. This method has been described earlier (12).

\section{HS-SPME-GC-MS procedure}

Clear glass vials $(6 \mathrm{~mL})$ with a stir bar were filled with $1 \mathrm{~mL}$ of urine, sealed with PTFE septum and 
holed aluminium caps. The vials were equilibrated at room temperature $\left(21^{\circ} \mathrm{C}\right)$ for $30 \mathrm{~min}$. Fused silica fibre $10 \mathrm{~mm}$ long, coated with a $100 \mu \mathrm{m}$ thick PDMS film was used (Supelco, Bellefonte, USA). The fibre was exposed to the headspace above the sample for $15 \mathrm{~min}$ at room temperature $\left(21^{\circ} \mathrm{C}\right)$. During the extraction, the urine sample was stirred (300 rpm). After the extraction, the fibre was pulled in the stainless steel needle and inserted into the SPI injector (septum-equipped programmable injector). Analytes were thermally desorbed from the SPME fibre at $200^{\circ} \mathrm{C}$ for $3 \mathrm{~min}$ and analysed using a Varian 3400 CX gas chromatograph with Saturn ion trap mass spectrometer operating in the electron impact (EI) mode. The components were injected onto the Rtx-5 (Restek, Bellefonte, USA) capillary column (30 $\mathrm{m} \times 0.25 \mathrm{~mm}$ I.D., $0.25 \mu \mathrm{m}$ film thickness). The oven temperature was kept at $35^{\circ} \mathrm{C}$ for $2 \mathrm{~min}$, and then the temperature was raised to $90{ }^{\circ} \mathrm{C}$ at $5^{\circ} \mathrm{C} \mathrm{min}{ }^{-1}$. Lateeluating compounds were removed by increasing the temperature to $300{ }^{\circ} \mathrm{C}$ at $50^{\circ} \mathrm{C} \mathrm{min}^{-1}$. The flow rate of helium carrier gas was $1 \mathrm{~mL} \mathrm{~min}^{-1}$. The delay time was $2 \mathrm{~min}$. Monitored ions were $\mathrm{m} / \mathrm{z} 78$ (benzene) and 91 (toluene, ethylbenzene, and xylenes).

\section{Analytical Validation}

Calibration curves were obtained by analysing urine spiked with (50-2000) ng L-1 of BTEX. Least-squares linear regression analysis was used to estimate the slopes $(b)$ and intercepts (a) of calibration curves $y=b x+a$, where $y$ is the chromatographic area of the analyte, and $x$ is the concentration of the analyte in urine $\left(\mathrm{ng} \mathrm{L}^{-1}\right)$.

The detection limit (DL) for each analysed aromatic hydrocarbon was calculated according to the equation:

$$
\mathrm{DL}=\left(3 S E_{a}+a\right) / b
$$

where $S E_{a}$ is the standard error of the intercept

The accuracy of the methods was obtained from six replicate analyses of urine samples spiked with $100 \mathrm{ng} \mathrm{L}^{-1}$ and $600 \mathrm{ng} \mathrm{L}^{-1}$ of BTEX using the reference standard.

The precision of the methods was expressed as relative standard deviation, RSD \%. The repeatability was also estimated from six replicate analyses of urine samples spiked with $100 \mathrm{ng} \mathrm{L}^{-1}$ and $600 \mathrm{ng} \mathrm{L}^{-1}$ of BTEX.

\section{Subjects and urine sampling}

BTEX were determined in 20 urine samples from healthy adults (10 non-smokers and 10 smokers) without any known occupational BTEX exposure. Median age of the subjects was 33 years, and $60 \%$ were women.

The first urine samples were collected in the morning in clean $80-\mathrm{mL}$ bottles, filled completely to avoid losses to the headspace and analysed on the day of collection using the HS-SPME-GC-MS procedure described above.

This study has been approved by the ethical committee of the Institute for Medical Research and Occupational Health, and has been performed according to the Declaration of Helsinki.

\section{Statistics}

We performed all statistical analyses using Statistica for Windows, release 5.5 (StatSoft Inc., Tulsa, Oklahoma, (USA). The results within groups are presented as median and range, and the significance of the difference between groups was calculated by using the Mann-Whitney $U$ test. Undetectable concentrations were set at $0.5 \mathrm{xDL}$.

\section{RESULTS AND DISCUSSION}

Figure 1 shows PT-GC-PID chromatogram of blank urine spiked with $800 \mathrm{ng} \mathrm{L}^{-1}$ of BTEX. Total ion current and single ion chromatograms obtained by HS-SPME-GC-MS, shown in Figure 2, correspond to the blank urine spiked with the same concentration of BTEX (800 ng L-1). Both described methods allowed separation and sensitive determination of BTEX in urine. The obtained peaks were sharp, narrow, and well separated from impurity peaks because of the pre-concentration step. Under the used experimental conditions, it was not possible to resolve $m$ - and $p$-xylene and consequently they were calculated together. As the photoionization detector is not sensitive enough for the HS-SPME analysis of BTEX

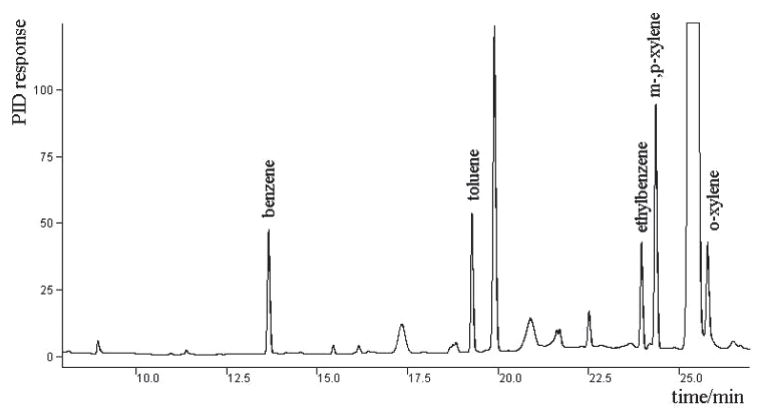

Figure 1 Chromatogram of blank urine spiked with $800 \mathrm{ng} \mathrm{L}^{-1}$ of BTEX and analysed using the PT-GC-PID procedure. 


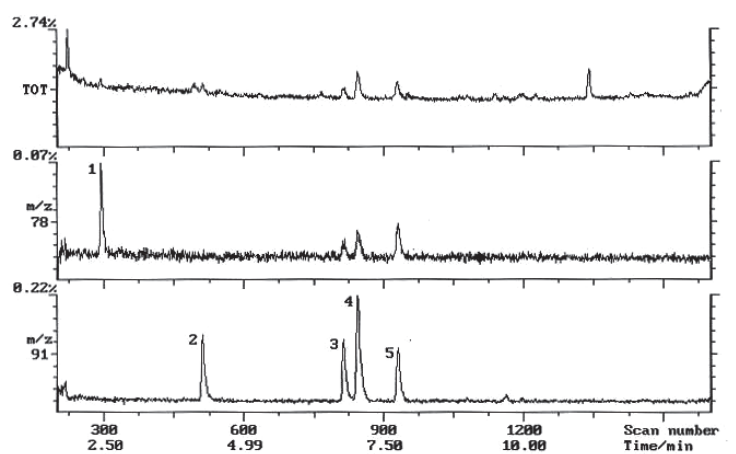

Figure 2 Total ion current and selected ion chromatograms of: (1) benzene ( $\mathrm{m} / \mathrm{z} 78)$, (2) toluene ( $\mathrm{m} / \mathrm{z}$ 91), (3) ethylbenzene ( $\mathrm{m} / \mathrm{z}$ 91), (4) $\mathrm{m} / \mathrm{p}$-xylene ( $\mathrm{m} / \mathrm{z}$ 91), and (5) o-xylene (m/z 91) in blank urine spiked with $800 \mathrm{ng} \mathrm{L}^{-1}$ of BTEX and analysed using the HS-SPME-GC-MS procedure.

in the urine at the concentration level resulting from environmental exposure, a mass spectrometer was used as a detector for HS-SPME analysis.

Table 1 summarises the calculated DL, accuracy, and repeatability for the determination of BTEX in the urine by both methods. Calibration curves were linear over the concentration range (50-2000) $\mathrm{ng} \mathrm{L}^{-1}$ with correlation coefficients $>0.998$ for both methods. The calculated DL ranged between $15 \mathrm{ng} \mathrm{L}^{-1}$ (for toluene) and $35 \mathrm{ng} \mathrm{L}^{-1}$ (for ethylbenzene) for PT-GC-PID, and between $39 \mathrm{ng} \mathrm{L}^{-1}$ (for toluene) and $50 \mathrm{ng} \mathrm{L}^{-1}$ (for benzene) for HS-SPME-GC-MS. According to our results, PT-GC-PID had 1.4 to 2 times lower DLs than HS-SPME, except for ethylbenzene, where the same DLs were calculated for both methods. We obtained lower DLs for PT-GC-PID than Fustinoni et al. (11) who used the same extraction method. Andreoli et al. (5) and Fustinoni et al. (1) obtained lower DLs than we did, using the same extraction method (HS-SPME), but our calculated DLs were significantly lower than those calculated by Krämer-Alkade et al. (16).

Accuracy for both methods was similar and greater than those previously reported $(10,11,16)$. Relative standard deviations at the two BTEX concentrations were also similar: RSD $\leq 11 \%$ and $\leq 10 \%$ for HSSPME-GC-MS and PT-GC-PID, respectively. They are comparable with repeatability studies reported by Fustinoni et al. (1) and Andreoli et al. (5) using HS-SPME-GC-MS and lower than Fustinoni et al. (11) using PT-GC-PID.

The use of an antifoam agent is critical in the PT analysis to prevent urine from foaming. We used Antifoam $\mathrm{A}$ and found that obligatory purification by lyophilisation after heating antifoam agent under a stream of dry nitrogen is absolutely needed, which makes PT analysis impractical. Besides, the PT method has more drawbacks: it requires complex and expensive instrumentation, it is time-consuming, and not suitable for routine analyses.

The sensitivity of HS-SPME-GC-MS was good enough for BTEX determination in the urine samples collected from the general population. Table 2 summarises mass concentrations of BTEX in the urine of 10 non-smokers and 10 smokers. Earlier findings showed no need for creatinine correction of BTEX in the urine (17). BTEX were measurable in all samples, except for benzene in one sample, and oxylene in four samples. Toluene had the highest and $\mathrm{o}$-xylene the lowest urinary concentration among the solvents studied. Smokers had significantly higher urinary BTEX concentrations than non-smokers. Our results were similar to those reported by others $(5$, $7,10,13)$. The exception in our study was toluene,

Table 1 Analytical parameters of PT-GC-PID and HS-SPME-GC-MS determination of BTEX at compound mass concentrations in the urine of $100 \mathrm{ng} \mathrm{L}^{-1}$ and $600 \mathrm{ng} \mathrm{L}^{-1}(\mathrm{n}=6)$

\begin{tabular}{|c|c|c|c|c|c|c|c|c|c|c|}
\hline \multirow{3}{*}{ Analyte } & \multicolumn{5}{|c|}{ PT-GC-PID } & \multicolumn{5}{|c|}{ HS-SPME-GC-MS } \\
\hline & \multirow{2}{*}{$\begin{array}{l}\text { Detection } \\
\text { limit / } \mathrm{ng} \mathrm{L}^{-1}\end{array}$} & \multicolumn{2}{|c|}{ Accuracy / \% } & \multicolumn{2}{|c|}{$\begin{array}{c}\text { Repeatability } \\
\text { RSD / \% }\end{array}$} & \multirow{2}{*}{$\begin{array}{c}\text { Detection } \\
\text { limit / } \\
n g L^{-1}\end{array}$} & \multicolumn{2}{|c|}{ Accuracy / \% } & \multicolumn{2}{|c|}{$\begin{array}{c}\text { Repeatability } \\
\text { RSD / } \%\end{array}$} \\
\hline & & $\begin{array}{c}100 \\
n g ~ L^{-1}\end{array}$ & $\begin{array}{c}600 \\
n g ~ L^{-1}\end{array}$ & $\begin{array}{c}100 \\
n g ~ L^{-1}\end{array}$ & $\begin{array}{c}600 \\
n g L^{-1}\end{array}$ & & $\begin{array}{c}100 \\
n g ~ L^{-1}\end{array}$ & $\begin{array}{c}600 \\
n g ~ L^{-1}\end{array}$ & $\begin{array}{c}100 \\
n g L^{-1}\end{array}$ & $\begin{array}{c}600 \\
\mathrm{ng} \mathrm{L}^{-1}\end{array}$ \\
\hline Benzene & 25 & 85 & 99 & 8 & 2 & 50 & 91 & 100 & 11 & 3 \\
\hline Toluene & 15 & 80 & 98 & 10 & 1 & 39 & 94 & 100 & 8 & 2 \\
\hline Ethylbenzene & 35 & 87 & 100 & 10 & 2 & 35 & 98 & 98 & 10 & 3 \\
\hline m/p-Xylene & 26 & 95 & 100 & 3 & 0.2 & 42 & 97 & 98 & 5 & 4 \\
\hline o-Xylene & 30 & 94 & 99 & 10 & 3 & 42 & 96 & 96 & 8 & 5 \\
\hline
\end{tabular}


Table 2 Mass concentrations $\left(n g L^{-1}\right)$ of BTEX in the urine of non-smokers $(n=10)$ and smokers $(n=10)$

\begin{tabular}{lccccc}
\hline \multirow{2}{*}{ Analyte } & \multicolumn{2}{c}{ Non-smokers } & \multicolumn{2}{c}{ Smokers } & Mann-Whitney \\
& Median & Range & Median & Range & U-test \\
& 175 & $<50-291$ & 502 & $245-635$ & $<0.001$ \\
\hline Benzene & 166 & $141-216$ & 633 & $184-886$ & $<0.001$ \\
\hline Toluene & 121 & $<35-175$ & 165 & $70-353$ & $<0.05$ \\
\hline Ethylbenzene & 329 & $104-465$ & 436 & $198-901$ & $<0.05$ \\
\hline m/p-Xylene & 42 & $<42-104$ & 96 & $60-213$ & $<0.05$ \\
\hline o-Xylene & & & & &
\end{tabular}

* Criterion for significance was $p<0.05$

which occurred in concentrations lower than those measured by Perbellini et al. (7) and Hung et al. (10). Our results were, however, higher than those reported in our previous study (17), probably due to a difference in sampling time; in this study we collected samples in the winter, and in the earlier study in the summer when lower concentrations of BTEX in air (affecting BTEX concentration in urine) were found because of reduced heating and enhanced photochemical degradation during the summer. In addition, general population spend more time inside the house during the winter and it is well known that indoor air concentrations of BTEX frequently exceed those outdoors (6).

\section{CONCLUSIONS}

Both methods showed very good repeatability, linearity and accuracy within the range studied. In addition, both methods are solvent-free, and do not require sample preparation. Extraction and preconcentration of BTEX are carried out in a single step, and detection limits in the range of $\mathrm{ng} \mathrm{L}^{-1}$ are easily achieved. The cost of the PT system is relatively high, and handling during analysis is much more complicated than for HS-SPME. Furthermore, retention times may vary because of pressure changes within the PT system. The main advantage of HS-SPME is that it is simple to use, and needs less complex instrumentation than PT, but it also requires immediate GC analysis of the volatile compounds. The shorter time required for the whole analytical process (32 min versus 45 min for PT), small sample volume (1 $\mathrm{mL}$ versus $10 \mathrm{~mL}$ for PT), and simple handling could be good reasons to recommend HS-SPME for routine analysis of BTEX in urine.

\section{REFERENCES}

1. Fustinoni S, Giampiccolo R, Pulvirenti S, Buratti M, Colombi A. Headspace solid-phase microextraction for the determination of benzene, toluene, ethylbenzene and xylenes in urine. J Chromatogr B 1999;723:10515.

2. Menendéz JCF, Sánchez mLF, Uría JES, Martínez EF, Sanz-Medel A. Static headspace, solid-phase microextraction and headspace solid-phase microextraction for BTEX determination in aqueous samples by gas chromatography. Anal Chim Acta 2000;415:9-20.

3. International Agency for Research on Cancer (IARC). Benzene. Monographs on the evaluation of the carcinogenic risk of chemicals to humans, suppl. 7. Lyon: IARC; 1987.

4. Schroers HJ, Jermann E, Begerow J, Hajimiragha $\mathrm{H}$, Chiarotti-Omar AM, Dunemann L. Determination of physiological levels of volatile organic compounds in blood using static headspace capillary gas chromatography with serial triple detection. Analyst 1998;123:715-20.

5. Andreoli R, Manini P, Bergamaschi E, Brustolin A, Mutti A. Solid-phase microextraction of gas chromatographymass spectrometry for determination of monoaromatic hydrocarbons in blood and urine: application to people exposed to air pollutants. Chromatographia 1999;50:167-72.

6. Ilgen E, Karfich N, Levsen K, Angerer J, Schneider P, Heinrich J, Wichmann HE, Dunemann L, Begerow J. Aromatic hydrocarbons in the atmospheric environment: Part I. Indoor versus outdoor sources, the influence of traffic. Atmos Environ 2001;35:1235-52.

7. Perbellini L, Pasini F, Romani S, Princivalle A, Brugnone F. Analysis of benzene, toluene, ethylbenzene and $\mathrm{m}$-xylene in biological samples from the general population. J Chromatogr B 2002;778:199-210.

8. Wallace L, Buckley T, Pellizzari E, Gordon S. Breath measurements as volatile organic compound biomarkers. Environ Health Perspect 1996;104(Suppl 5):861-9. 
9. Gobba F, Ghittori S, Imbriani M, Maestri L, Capodaglio E, Cavalleri A. The urinary excretion of solvents and gases for the biological monitoring of occupational exposure: a review. Sci Total Environ 1997;199:3-12.

10. Hung IF, Lee SA, Chen RK. Simultaneous determination of benzene, toluene, ethylbenzene, and xylenes in urine by thermal desorption-gas chromatography. J Chromatogr B 1998;706:352-7.

11. Fustinoni S, Buratti M, Giampiccolo R, Pulvirenti S, Colombi A. Monitoraggio biologico dell'esposizione a solventi: metodo per la determinazione gascromatografica degli idrocarburi aromatici nel sangue e nell'urina [Biological monitoring of exposure to solvents: a method for the gas-chromatographic determination of aromatic hydrocarbons in the blood and urine, in Italian]. Med Lav 1996;87:63-75.

12. Brčić I, Skender Lj. Determination of benzene, toluene, ethylbenzene, and xylenes in urine by purge and trap gas chromatography. J Sep Sci 2003;26:1225-9.
13. Minoia C, Meroni G, Aprea C, Oppezzo MC, Magnaghi S, Sciarra G, Barisano A, Fiorentino mL, Berri A, Bellinzona M, Robustelli della Cuna FS, Frigerio F, Schiavi A, Di Gregorio L. Environmental and urinary reference values as markers of exposure to hydrocarbons in urban areas. Sci Total Environ 1996;192:163-82.

14. Zhang ZY, Pawliszyn J. Headspace solid-phase microextraction. Anal Chem 1993;65:1843-52.

15. Miller JC, Miller JN, editors. Statistics for Analytical Chemistry. $1^{\text {st }}$ ed. Chichester: Ellis Horwood; 1984.

16. Krämer Alkade T, Peralba MCR, Zini CA, Caramão EB. Quantitative analysis of benzene, toluene, and xylenes in urine by means of headspace solid-phase microextraction. J Chromatogr A 2004;1027:37-40.

17. Skender Lj, Brčić I, Karačić V. Urine analysis for the evaluation of environmental exposure to aromatic hydrocarbons. Arch Environ Health 2004;59:237-44. 


\section{Sažetak}

\section{USPOREDBA DINAMIČKE ANALIZE PARA IZNAD OTOPINE I MIKROEKSTRAKCIJE ANALITA NA ČVRSTOJ FAZI ZA PLINSKOKROMATOGRAFSKO ODREĐIVANJE BTEX-a U URINU}

Cilj ovog rada bio je usporediti dva postupka ekstrakcije za plinskokromatografsko određivanje benzena, toluena, etilbenzena i izomera ksilena u urinu. Uspoređene su dinamička analiza para iznad otopine (tzv. purge and trap) uz fotoionizacijski detektor i mikroekstrakcija analita na čvrstoj fazi uz detektor spektrometar masa. Rezultati upućuju na linearnost odziva detektora u ispitivanome koncentracijskom području [(502000) ng L-1 , zadovoljavajuću točnost ( $80 \%-100 \%$ i ponovljivost (RSD $\leq 11 \%$ ). Postignute su niske granice detekcije za obje metode. Mikroekstrakcija analita na čvrstoj fazi uz detektor spektrometar masa pokazala se jednostavnijom i bržom za izvođenje pa se preporučuje za rutinsko određivanje BTEX-a u urinu. Metoda je primijenjena za analizu tih spojeva u uzorcima urina nepušača $(n=10)$ i pušača $(n=10)$.

KLJUČNE RIJEČI: GC-MS, PID, ponouljivost, PT, SPME, točnost

\section{CORRESPONDING AUTHOR:}

Irena Brčić Karačonji

Institute for Medical Research and Occupational Health PO Box 291, HR-1000 Zagreb, Croatia

E-mail: ibrcic@imi.hr 